\title{
Integration of some organic amendments and the predatory nematode, Fictor composticola, for the management of Meloidogyne incognita in cucumber
}

\author{
Harjot Singh Sidhu ${ }^{*}$ and Rambir Singh Kanwar
}

\begin{abstract}
Background: Organic amendments are well known for influencing soil nematode community structure, diversities, and activities. Most of the previous studies focused on effects of organic amendments on plant-parasitic nematodes, but only a few investigated the effect of combination of biocontrol agents and organic amendments on soil nematodes.

Main body: Different organic amendments (neem cake, poultry manure, and neem leaves) were combined with the predatory nematode, Fictor composticola, for the control of root-knot nematode, Meloidogyne incognita, in cucumber. Organic amendments were mixed in pots containing $1 \mathrm{~kg}$ soil, 15 days before sowing. Cucumber (cv. $\mathrm{CCH}-1$ ) plants grown in these pots were inoculated by $2000 \mathrm{~J}_{2}$ of $\mathrm{M}$. incognita and $400 \mathrm{~F}$. composticola per pot, after 1 week of germination. Fictor composticola in combination with chicken manure + neem cake + neem leaves was found the best mixture for reducing the number of galls, egg masses, and final root-knot nematode population. The predator's population reached the maximum in this treatment. All combinations of organic amendments in the presence of F. composticola were found significantly superior over inoculated check in reducing nematode's population and in improving plant growth over the un-inoculated check.

Conclusions: Data indicated the suitability of using the predatory nematode, F. composticola, and organic amendments for potential use in sustainable nematode management strategies.
\end{abstract}

Keywords: Biological control, Predatory nematode, Fictor composticola, Meloidogyne incognita, Organic amendment

\section{Key messages}

- In context to environmental safety, the application of organic amendments is still the primary option to manage phytonematodes. In this study, we demonstrated that predatory nematode, Fictor composticola, which was highly effective against $M$. incognita in earlier studies, was combined with organic amendments has significantly enhanced cucumber growth in pot trials.

* Correspondence: harjotsingh@hau.ac.in

Department of Nematology, CCS Haryana Agricultural University, Hisar 125004, India

\section{Springer Open}

- To our knowledge, this is the first report of the diplogasterid predator in combination with organic amendments against $M$. incognita in cucumber production.

- In a cucumber pothouse, the predator population was maximum in combination of three amendments (chicken manure + neem cake + neem leaves) and their incorporation showed some growth promotion effect in cucumber.

\section{Background}

Cucumber is a leading vegetable crop planted in greenhouses (Mao et al. 2016). The crop is attacked by several (c) The Author(s). 2020 Open Access This article is licensed under a Creative Commons Attribution 4.0 International License, which permits use, sharing, adaptation, distribution and reproduction in any medium or format, as long as you give appropriate credit to the original author(s) and the source, provide a link to the Creative Commons licence, and indicate if changes were made. The images or other third party material in this article are included in the article's Creative Commons licence, unless indicated otherwise in a credit line to the material. If material is not included in the article's Creative Commons licence and your intended use is not permitted by statutory regulation or exceeds the permitted use, you will need to obtain permission directly from the copyright holder. To view a copy of this licence, visit http://creativecommons.org/licenses/by/4.0/. 
nematodes, which have become a serious threat, particularly under protected cultivation (Patil et al. 2017). Rootknot nematodes (Meloidogyne incognita and $M$. javanica) are the prominent problem that has led to failure/closure of many polyhouses in India. Although considerable work has been carried out during the last few decades on the use of organic amendments for reducing the plant-parasitic nematodes (Singh and Sitaramaiah 1973; Rodriguez-Kabana 1986), but almost no work has been done to recognize the effect of organic amendment over predatory nematodes of Order Diplogasterida, which are known to feed upon the plant-parasitic nematodes and may serve as biological control agents. Fictor composticola, a predatory nematode that has shown a potential to control mycophagous and plantparasitic nematodes (Kanwar et al. 2009; Bajaj and Kanwar 2015). The present work was undertaken to study the management of $M$. incognita by integrating $F$. composticola with some organic amendments, found effective in preliminary trials (Sidhu and Kanwar 2019).

\section{Materials and methods Location}

The experiment was carried out under the screen house conditions in the Department of Nematology, Chaudhary Charan Singh Haryana Agricultural University (CCS HAU), Hisar, Haryana, India during May-June 2019.

\section{Nematode inoculum}

Pure culture of $M$. incognita was maintained on brinjal plants (cv. BR 112) in pots. The culture of $F$. composticola was maintained on $1 \%$ water agar medium in Petri plates in a BOD incubator at $25 \pm 2{ }^{\circ} \mathrm{C}$, using $M$. incognita juveniles as prey. The culture was used for experimentation. For inoculation in pots, the predatory nematodes from culture plates were extracted in sterile water inside a beaker. The predatory nematodes in the beaker were counted and used for the inoculation as per the requirement of the experiment.

\section{Organic amendments}

Fresh leaves of neem (Azadirachta indica) were collected and chopped by scissors in small pieces and used freshly during the experiment. Locally available neem seed cake was dried in shade, ground using a laboratory grinder, and passed through a 20 -mesh sieve $(840 \mu \mathrm{m})$. Chicken manure was available from CCS HAU, Hisar.

\section{Experimental setup}

Clay pots of $1 \mathrm{~kg}$ capacity each were filled with autoclaved soil. Neem cake, neem leaves, and chicken manure were combined with $F$. composticola (Table 1). Organic amendments were mixed in pots for 15 days before sowing and light irrigation was applied. Three nonamended control treatments, viz., $M$. incognita alone, $F$. composticola alone, and un-inoculated were kept. Pots were arranged in a completely randomized design, 4 replicates per treatment. Two seeds of cucumber (cv. $\mathrm{CCH}-1)$ were sown in each pot and 1 week after germination, one plant/pot was retained. One-week-old seedlings were inoculated by pencil's hole method, at 2000 freshly hatched $\mathrm{J}_{2}$ of M. incognita and $400 \mathrm{~F}$. composticola per pot.

\section{Maintenance of plants}

After germination, plants were regularly watered and general care was taken. Hoagland solution was applied at 10 days' interval. Hand hoeing was carried out at desired intervals for proper aeration. Yellow trap cards were installed to manage the whitefly population and 3 sprays of Nimbicidin at $0.2 \%$ were applied to protect the crop from insects.

\section{Observations}

Observations were recorded 45 days after inoculation on plant height, shoot weight, root weight, number of galls, egg masses, and final nematode population in the soil. The number of galls and egg masses on roots were counted with the help of the magnifying lens. Compound galls were counted as single gall. Nematode populations were recorded at $\times 40$ magnifications using a stereoscopic binocular microscope.

\section{Temperature data}

Weekly temperature data of the experimental period were obtained from the Department of Agricultural Meteorology, CCS HAU, Hisar, and presented in Fig. 1.

\section{Statistical analysis}

Data were subjected to analysis of variance (ANOVA), and the means were compared with a critical difference. A significance level of $P \leq 0.05$ was used in all analyses. Nematode data were transformed, using square root transformation to homogenize error variances. All calculations were performed with the OPSTAT software available online at the website of CCS HAU, Hisar (www.hau.ac.in).

\section{Results and discussion}

The present study shows that the population of $M$. incognita recovered after harvest was significantly lower $(73.75 / 200 \mathrm{cc})$ in treatment where a combination of 3 amendments (chicken manure + neem cake + neem leaves) were incorporated into the soil than the treatments, where 2 amendments [neem cake + neem leaves (111.25/200 cc); chicken manure + neem leaves (131.25/ $200 \mathrm{cc})$; chicken manure + neem cake $(168.75 / 200 \mathrm{cc})]$ were added to the soil. The use of organic amendments is effective and environmentally safe management of plant-parasitic nematodes and many other crop pests 
Table 1 Effect of Fictor composticola and organic amendments in different combinations on growth parameters of cucumber infected with Meloidogyne incognita

\begin{tabular}{|c|c|c|c|}
\hline Treatments & Plant height $(\mathrm{cm})$ & $\begin{array}{l}\text { Fresh shoot } \\
\text { weight }(g)\end{array}$ & $\begin{array}{l}\text { Fresh root } \\
\text { weight }(g)\end{array}$ \\
\hline F. composticola + neem cake $7.5 \mathrm{~g} / \mathrm{pot}+$ neem leaves $7.5 \mathrm{~g} / \mathrm{pot}+\mathrm{M}$. incognita & 29.55 & 28.25 & 3.95 \\
\hline F. composticola + chicken manure7.5 g/pot + neem cake7.5 g/pot + M. incognita & 32.28 & 28.59 & 3.80 \\
\hline F. composticola + neem leaves $7.5 \mathrm{~g} /$ pot + chicken manure $7.5 \mathrm{~g} / \mathrm{pot}+M$. incognita & 30.35 & 28.19 & 3.68 \\
\hline $\begin{array}{l}\text { F. composticola + chicken manure } 5.0 \mathrm{~g} / \mathrm{pot}+\text { neem cake } 5.0 \mathrm{~g} / \mathrm{pot}+\text { neem leaves } \\
5.0 \mathrm{~g} / \mathrm{pot}+\mathrm{M} \text {. incognita }\end{array}$ & 49.18 & 42.73 & 5.74 \\
\hline F. composticola alone & 25.73 & 15.07 & 2.41 \\
\hline Inoculated control (M. incognita alone) & 16.08 & 4.65 & 3.11 \\
\hline Un-inoculated control & 25.70 & 17.99 & 4.80 \\
\hline CD at $5 \%$ & 3.12 & 2.58 & 0.90 \\
\hline
\end{tabular}

F. composticola, 400 individuals per $\mathrm{kg}$ of soil

Root-knot nematode inoculum, $2000 \mathrm{~J}_{2} / \mathrm{kg}$ soil

and pathogens (Atolani and Fabiyi 2020). Various organic amendments release nematoxic compounds such as organic acids, nitrogenous compounds like ammonia, or various plant secondary metabolites during their decomposition (Rodriguez-Kabana et al. 1987; Akhtar and Malik 2000).

\section{Plant growth}

Data of plant height, shoot weight, and root weight are presented in Table 1. Plant height in all treatments was significantly taller than the plants inoculated with the root-knot nematode alone. The maximum plant height $(49.18 \mathrm{~cm})$ was recorded in case of $F$. composticola + chicken manure + neem cake + neem leaves. The plant height was taller in the plants inoculated with F.composticola alone than those inoculated with $M$. incognita alone, although it was statistically at par with uninoculated plants. Height was similar in the plants inoculated with chicken manure, neem cake, and neem leaves, in combinations of 2, but more than that inoculated with $M$. incognita or un-inoculated.

Fresh shoot weight was higher in all the treatments than in case of $M$. incognita alone. Shoot weight in $F$. composticola + chicken manure + neem cake + neem leaves was significantly higher than at all other treatments. All combinations of organic amendments in the presence of $F$. composticola were found significantly superior over un-inoculated check in improving plant weight. All the treatments having different combinations of amendments with $F$. composticola were statistically at par with each other, though they had more shoot weight than the un-inoculated check. Shoot weight in inoculated control was minimum $(4.65 \mathrm{~g})$ and significantly lower than all other treatments.

Root weight was maximum $(5.74 \mathrm{~g})$ in the treatment having $F$. composticola with chicken manure + neem cake + neem leaves, which was significantly higher than all other treatments. Fresh root weight in all the treatments was higher than F. composticola alone. Root

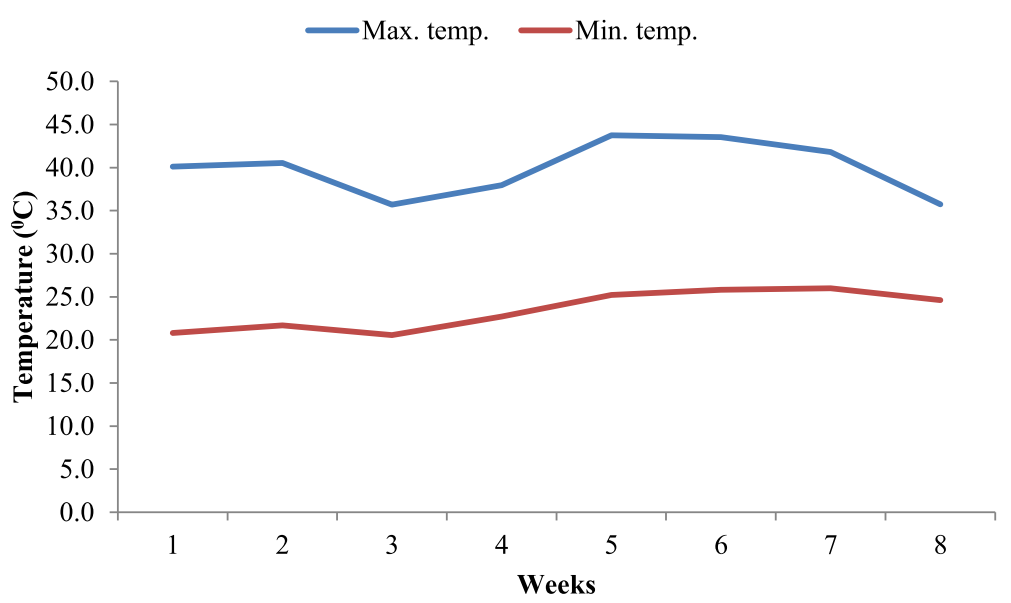

Fig. 1 Maximum and minimum temperature during the experimental period (3.5, 2019-16.6, 2019) 
weight in the treatments, received combinations of the 2 organic amendments was similar but less than at uninoculated control (Table 1).

When F. composticola was combined by organic amendments, the results showed that plant growth characteristics increased in all treatments than at the treatment inoculated with root-knot nematode alone. Plant growth in $F$. composticola + chicken manure + neem cake + neem leaves was significantly higher than all other treatments (Table 1). All treatments having different combinations of amendments with $F$. composticola had higher plant growth than un-inoculated check and it was minimum in inoculated control (Fig. 2).

\section{Root-knot nematode}

Numbers of galls, egg masses, and root-knot nematode populations are presented in Table 2. Indiscrete galls were observed on cucumber roots receiving various treatments where root-knot nematode was inoculated (Fig. 3). All the amended treatments showed significantly lesser gall formation than the inoculated control.

Minimum egg masses (11.75) were recorded in case of F. composticola + chicken manure + neem cake + neem leaves, while the maximum (157.5) was recorded in inoculated check. There was an overall decline in the mean egg masses counts in all treatments over an inoculated check and all the treatments differed significantly from inoculated check but they were at par with each other.

Soil population of the root-knot nematode was the lowest $(73.75 / 200 \mathrm{cc})$ in case of $F$. composticola + chicken manure + neem cake + neem leaves and it was statistically lower than other treatments. The highest nematode count ( 1091.25 per $200 \mathrm{cc}$ soil) was recorded in nematode inoculated control. In all other treatments, the nematode population was significantly lower than at the inoculated control.

Obtained results revealed that a minimum number of galls, number of egg masses, and nematode reproduction were recorded in the treatment of $F$. composticola + chicken manure + neem cake + neem leaves, while the maximum was found in inoculated check (Table 2). Nematode's population in all treatments was less than in the plants inoculated with $M$. incognita alone. Application of organic amendments along with $F$. composticola resulted in a fewer number of galls and egg masses than M. incognita alone. Chavarria-Carvajal et al. (2001) found that combinations of organic amendments and benzaldehyde were effective in reducing $M$. incognita and other plant-parasitic nematodes. However, numbers of root-knot nematodes were lower due to metabolites released through the decomposition of organic amendment and predatory nematode populations were able to have more impact and further reduce root-knot nematode numbers.

\section{Population of predator}

The predator's population was affected by the combinations of chicken manure, neem cake, and neem leaves as amendments. The population reached the maximum ( 38.75 per $200 \mathrm{cc}$ soil) in the integrated treatment and the minimum $(11.5 / 200 \mathrm{cc})$ in the case of F. composticola alone treatment (Fig. 4).

In the present study, a high population of the predatory nematode was recovered where chicken manure was added to the soil than other organic amendments. Perhaps it supported the higher microbial population,

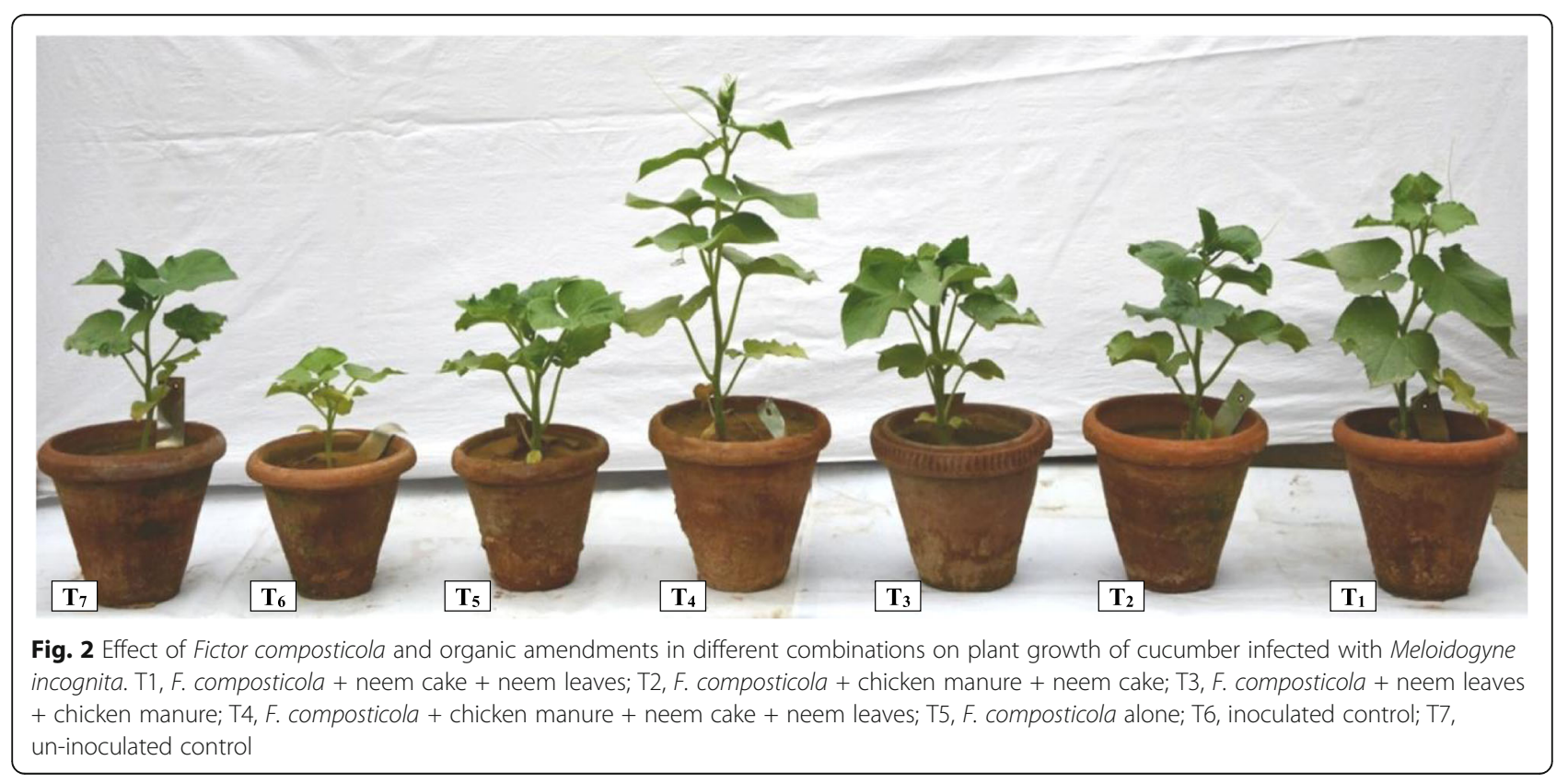


Table 2 Effect of Fictor composticola and organic amendments in different combinations on gall formation and reproduction of Meloidogyne incognita

\begin{tabular}{llll}
\hline Treatments & $\begin{array}{l}\text { Number of } \\
\text { galls/plant }\end{array}$ & $\begin{array}{l}\text { Number of egg } \\
\text { masses/plant }\end{array}$ & $\begin{array}{l}\text { Final nematode } \\
\text { population/200 cc soil }\end{array}$ \\
\hline F. composticola + neem cake7.5 g/pot + neem leaves 7.5 g/pot + M. incognita & $17.75(4.32)$ & $11.75(3.57)$ & $111.25(10.57)$ \\
F. composticola + chicken manure7.5 g/pot + neem cake $7.5 \mathrm{~g} /$ pot + M. incognita & $37.50(6.19)$ & $21.00(4.68)$ & $168.75(12.97)$ \\
F. composticola + neem leaves7.5 g/pot + chicken manure7.5 g/pot + M. incognita & $29.00(5.46)$ & $18.25(4.37)$ & $131.25(11.40)$ \\
F. composticola + chicken manure $5.0 \mathrm{~g} /$ pot + neem cake $5.0 \mathrm{~g} /$ pot + neem leaves & $17.25(4.26)$ & $10.00(3.30)$ & $73.75(8.63)$ \\
5.0 g/pot + M. incognita & & & $1091.25(32.99)$ \\
Inoculated control (M. incognita alone) & $82.00(9.02)$ & $157.50(12.47)$ & $(1.18)$ \\
CD at 5\% & & $(1.42)$ & (2.12) \\
\hline
\end{tabular}

Figure in the parentheses are square root transformed values

especially bacteria, which are fed by $F$. composticola. With the addition of organic amendments, increased populations of bacterivorous nematodes were obtained because of higher populations of bacteria during the process of decomposition (Bulluck and Ristaino 2002). Similar results were obtained by Wachira et al. (2009) who suggested that more populations of predacious nematodes were recorded in the soils amended with chicken manure in tomato crop. The carnivorous Clarkus papillatus was the most abundant in amended farms in comparison to conventional farms. With a cruciferous cover crop, the numbers of carnivorous Mylonchulus sigmaturus ( $M$. sigmaturus) were the highest (Van Diepeningen et al. 2006).

In the present study, the final population of the predatory nematode was less than its initial population. This may be due to the high temperature during the experimental period, which was unfavorable for $F$. composticola (Keshari 2016). The present results also support the findings of Ahmad and Jairajpuri (1982) that the minimum population of predatory nematodes was found when encountered with the maximum soil temperature. There was a short generation time of F. composticola than M. incognita (Bajaj and Kanwar 2015). It may also be hypothesized that when $F$. composticola alone with $M$. incognita was added to the pots, the root-knot larvae escaped predation by entering roots because penetration by most root-knot larvae into roots can be accomplished within $48 \mathrm{~h}$ (Gourd et al. 1993). Thus, it seems clear that the non-availability of prey linked to reduce predatory nematode numbers at the end of the experiment. The final population density of $F$. composticola decreased than the initially added density. Obtained results are in harmony with those reported by Van Diepeningen et al. (2006) and $\mathrm{Hu}$ and Qi (2010) who found that omnivorous and predatory nematodes first increased after amending the soil and then decreased with time. In contrast, there was a twofold increase in Mononchoides

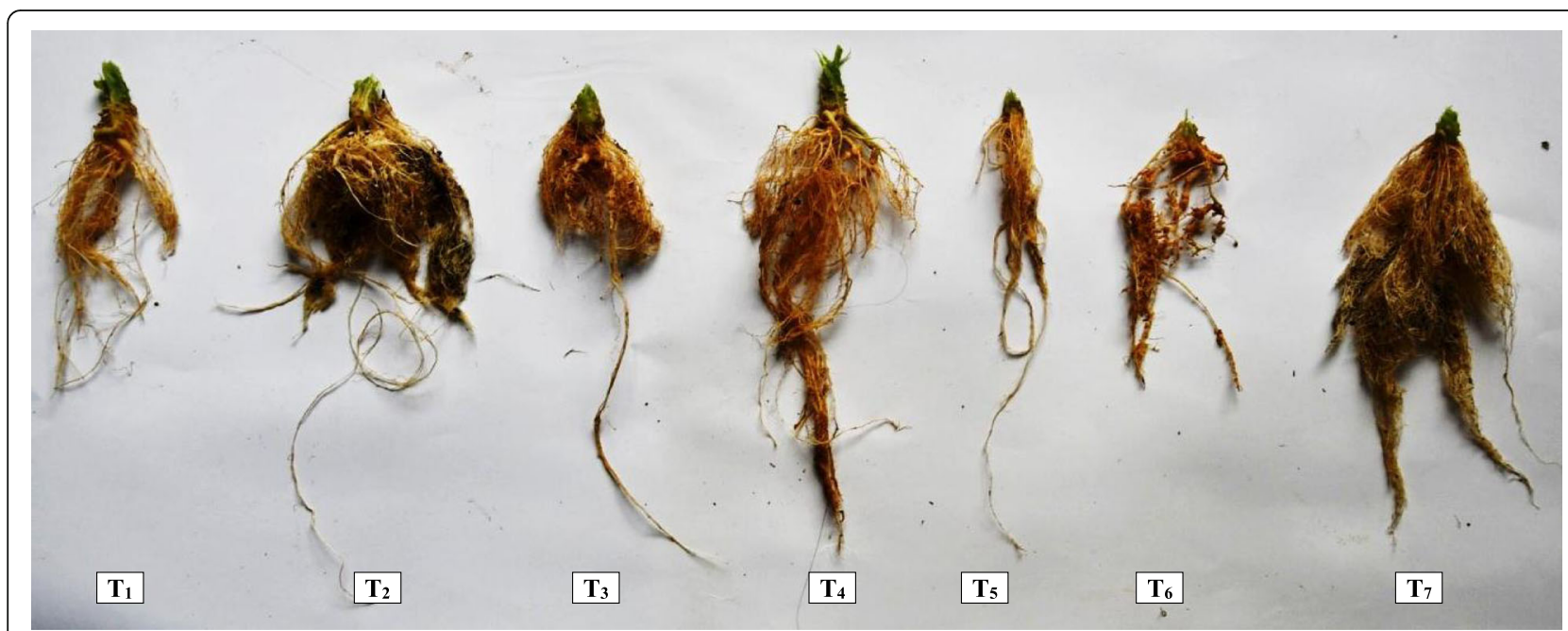

Fig. 3 Effect of Fictor composticola and organic amendments in different combinations on gall formation by Meloidogyne incognita on cucumber roots. T1, F. composticola + neem cake + neem leaves; T2, F. composticola + chicken manure + neem cake; T3, F. composticola + neem leaves + chicken manure; T4, F. composticola + chicken manure + neem cake + neem leaves; T5, F. composticola alone; T6, inoculated control; T7, un-inoculated control 


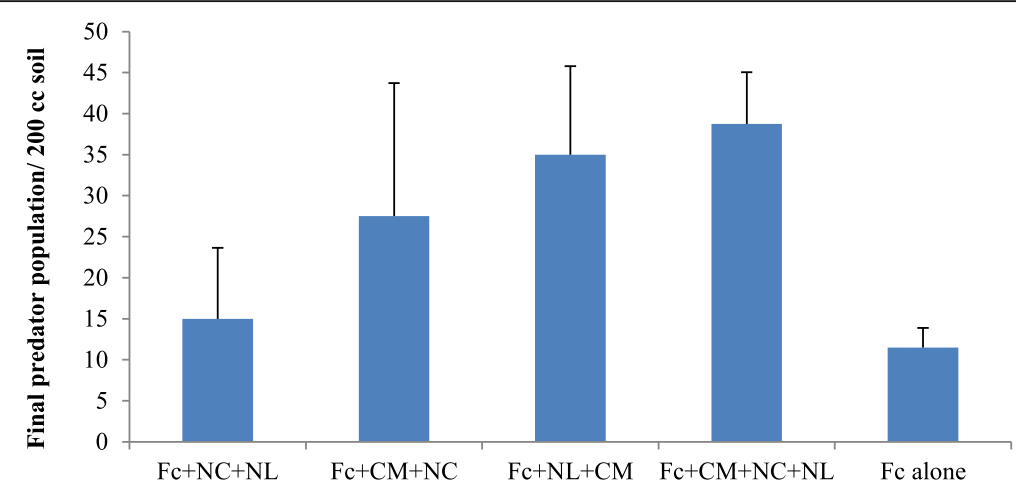

Treatments

Fig. 4 Final population of Fictor composticola in presence of different combinations of organic amendments (NC, neem cake; CM, chicken manure; NL, neem leaves; Fc, F. composticola)

fortidens (M. fortidens) between inoculation and harvest during pot experiments (Khan and Kim 2005). Lal et al. (1983) also found the number of the predator population increased by about twofold markedly with the input of green manure to the soil.

\section{Conclusions}

All combinations of organic amendments in the presence of $F$. composticola were effective in suppressing root-knot nematode population as well as improving plant growth. The predator population was also maximum in the treatment where a combination of 3 amendments (chicken manure + neem cake + neem leaves) was incorporated into the soil. The results of this study seem to indicate that predatory nematode, Fictor composticola, and organic amendments could be considered potential candidates as alternative to pesticides, mainly suitable to organic farming, where a few and poorly effective tools are available not only for the control of soil pests and pathogens but also eligible for sustainable nematode management in conventional crops.

\section{Abbreviations}

F. composticola: Fictor composticola; M. fortidens: Mononchoides fortidens; M. incognita: Meloidogyne incognita

\section{Acknowledgements}

Temperature data for the experimental period provided by the Department of Agricultural Meteorology, CCS HAU, Hisar, India, is gratefully acknowledged.

\section{Authors' contributions}

The concept and design of the experiments were prepared by both authors. HSS conducted the experiments, analyzed the results, and wrote the manuscript. RSK supervised the results analysis and corrected the manuscript draft. The authors read and approved the final manuscript.

\section{Funding}

This study is a part of a PhD Thesis of the senior author. No funding was obtained from any source.

\section{Availability of data and materials}

All data generated and/or analyzed during the present study are available in the manuscript, and the corresponding author has no objection to the availability of data and materials.

\section{Ethics approval and consent to participate}

The study was conducted on predatory and plant-parasitic nematode species that are abundant in the environment and does not require ethical approval.

\section{Consent for publication}

Not applicable

\section{Competing interests}

Both authors declare that they have no conflict of interest.

Received: 13 September 2020 Accepted: 6 December 2020

Published online: 14 December 2020

\section{References}

Ahmad N, Jairajpuri MS (1982) Population fluctuations of predatory nematode Parahadronchus shakili (Jairajpuri, 1969) Mulvey, 1978 (Mononchida). In: Proc. Symp. Ecol. Anim. Popul. India, pp 1-12

Akhtar M, Malik A (2000) Roles of organic soil amendments and soil organisms in the biological control of plant-parasitic nematodes: a review. Bioresour Technol 74:35-47. https://doi.org/10.1016/S0960-8524(99)00154-6

Atolani O, Fabiyi OA (2020) Plant parasitic nematodes management through natural products: current progress and challenges. In: Ansari R, Rizvi R, Mahmood I (eds) Management of Phytonematodes: recent advances and future challenges, Singapore, https://doi.org/10.1007/978-981-15-4087-5 13

Bajaj HK, Kanwar RS (2015) Biology and predatory attributes of a diplogasterid nematode, Fictor composticola Khan et al., 2008. Helminthologia 52:50-57. https://doi.org/10.1515/helmin-2015-0009

Bulluck LR, Ristaino JB (2002) Effect of synthetic and organic soil fertility amendments on southern blight, soil microbial communities and yield of processing tomatoes, soil microbial communities and yield of processing tomatoes. Phytopathology 92:181-189. https://doi.org/10.1094/PHYTO.2002. 92.2.181

Chavarria-Carvajal JA, Rodriguez-Kabana R, Kloepper JW, Morgan-Jones G (2001) Changes in populations of microorganisms associated with organic amendments and benzaldehyde to control plant-parasitic nematodes. Nematropica 31:165-180 
Gourd TR, Schmitt DP, Barker KR (1993) Penetration rate by second stage juveniles of Meloidogyne spp. and Heterodera glycines into soybean roots. J Nematol 25:38-41 PMID: 19279739; PMCID: PMC2619352

Hu C, Qi Y (2010) Abundance and diversity of soil nematodes as influenced by different types of organic manure. Helminthologia 47:58-66. https://doi.org/ 10.2478/s11687-010-0009-8

Kanwar RS, Bajaj HK, Nandal SN (2009) Potential of a predatory nematode, Fictor composticola as a biocontrol agent of nematode pest of mushroom. In: Parmar YS (ed) Abstract of the paper presented in National Symposium. University of Horticulture and Forestry, Solan 8-9 July 2009

Keshari N (2016) Predatory behaviour of Fictor composticola Khan et al. and its potential for the management of nematode pests of button mushroom Dissertation, CCS Haryana Agricultural University

Khan Z, Kim YH (2005) The predatory nematodes, Mononchoides fortidens (Nematoda: Diplogasterida) suppresses the root-knot nematode, Meloidogyne arenarea, in potted field soil. Biol Control 35:78-82. https://doi.org/10.1016/j, biocontrol.2005.05.015

Lal A, Sanwal KC, Mathur VK (1983) Changes in the nematode populations of undisturbed land with the introduction of land development practices and cropping sequence. Indian J Nematol 13:133-140

Mao LG, Wang QX, Yan DD, Liu PF, Shen J, Fang WS, Hu XM, Li Y, Ouyang CB, Guo MX, Cao AC (2016) Application of the combination of 1, 3dichloropropene and dimethyl disulfide by soil injection or chemigation: effects against soilborne pests in cucumber in China. J Integr Agric 15:145152. https://doi.org/10.1016/S2095-3119(15)61065-6

Patil J, Kumar A, Goel SR (2017) Incidence of plant parasitic nematodes associated with polyhouses under protected cultivation in Haryana. Environ Ecol 35:1870-1873

Rodriguez-Kabana R (1986) Organic and inorganic nitrogen amendments to soil as nematode suppressants. J Nematol 18:129-135

Rodriguez-Kabana R, Morgan-Jones G, Chet I (1987) Biological control of nematodes. Soil amendments and microbial antagonists. Plant Soil 100:237247

Sidhu HS, Kanwar RS (2019) Role of predatory nematode, Fictor composticola and organic amendments in suppressing root-knot nematode, Meloidogyne incognita in cucumber. In: Abstract of the paper presented in international conference on global perspective in agricultural and applied sciences for food and environmental security (GAAFES-2019). Kumaun University, Nainital

Singh RS, Sitaramaiah K (1973) Control of plant parasitic nematodes with organic amendments of soil. In: Experimental Station Bulletin no. 6. G.B. Pant University of Agriculture and Technology, Pantnagar, p 289

Van Diepeningen AD, De Vos OJ, Korthals GW, Van Bruggen AHC (2006) Effects of organic versus conventional management on chemical and biological parameters in agricultural soils. Appl Soil Ecol 31:120-135. https://doi.org/10. 1016/j.apsoil.2005.03.003

Wachira PM, Kimenju JW, Okoth SA, Mibey RK (2009) Stimulation of nematodedestroying fungi by organic amendments applied in management of plant parasitic nematode. Asian J Plant Sci 8:153-159. https://doi.org/10.3923/ajps. 2009.153.159

\section{Publisher's Note}

Springer Nature remains neutral with regard to jurisdictional claims in published maps and institutional affiliations.

\section{Submit your manuscript to a SpringerOpen ${ }^{\circ}$ journal and benefit from:}

- Convenient online submission

- Rigorous peer review

- Open access: articles freely available online

- High visibility within the field

- Retaining the copyright to your article

Submit your next manuscript at $\boldsymbol{\nabla}$ springeropen.com 